\title{
Population study of the filamentous sulfur bacteria Thioploca spp. off the Bay of Concepción, Chile
}

\author{
Heide N. Schulz ${ }^{1, *}$, Bettina Strotmann ${ }^{1}$, Victor A. Gallardo ${ }^{2}$, Bo B. Jørgensen ${ }^{1}$ \\ ${ }^{1}$ Max Planck Institute for Marine Microbiology, Celsiusstrasse 1, 28359 Bremen, Germany \\ ${ }^{2}$ Estación de Biología Marina, Dichato, Universidad de Concepción, Casilla 160-C, Concepción, Chile
}

\begin{abstract}
A population of filamentous sulfur bacteria Thioploca spp. living in the Bay of Concepción, Chile, and the adjoining shelf area was sampled for $14 \mathrm{mo}$ at 4 to $6 \mathrm{wk}$ intervals to investigate the influence of seasonal variations in upwelling intensity and oxygen concentrations on the population dynamics. The Thioploca population was described by its biomass, total number and diameter of sheaths, number of trichomes and species per sheath, and abundance and depth distribution of different morphological forms, e.g. trichome diameters and ratios of cell-length to diameter. Throughout the summer of 1996, oxygen concentrations in the bottom water were near zero, nitrate was 10 to $20 \mu \mathrm{M}$ and the biomass was high, up to $160 \mathrm{~g} \mathrm{~m}^{-2}$ wet weight without sheaths. During winter, the biomass declined due to higher oxygen concentrations under reduced upwelling intensity. The depth distribution of Thioploca spp. changed strongly with seasonal variations, but the population structure remained mainly unchanged. During the 'El Niño' event in 1998, with high oxygen and low primary production, the biomass was very low. In the Bay of Concepción 2 populations of filamentous sulfur bacteria were observed, filaments with short cells in sheaths, populating the upper $7 \mathrm{~cm}$ of the sediment, and filaments without sheaths living at the sediment surface.
\end{abstract}

KEY.WORDS: Thioploca - Population dynamics - Biomass · Species distribution · Bay of Concepción · Upwelling · Chile

\section{INTRODUCTION}

The filamentous sulfur bacteria of the genus Thioploca are abundant in the upwelling areas along the coast of Chile and Peru (Gallardo 1977, Rosenberg et al. 1983). In contrast to the free-living, closely related sulfur bacteria Beggiatoa spp., Thioploca filaments live as bundles within a common sheath. The mainly vertically oriented sheaths may reach down many $\mathrm{cm}$ into the sediment (Schulz et al. 1996). They are found in shelf sediments within the oxygen minimum zone and reach a high biomass of up to $1 \mathrm{~kg} \mathrm{~m}^{-2}$ (fresh weight including sheaths) (Gallardo 1977), being at times the most abundant benthic organism in the sediment. Studies on partially purified mixed cultures of Thioploca spp. showed that they oxidize sulfide to sulfate while reducing nitrate to ammonium (Otte et al. 1999). The bacteria store

•E-mail: hschulz@mpi-bremen.de elemental sulfur as globules in the peripheral cytoplasmic layer and concentrate nitrate in a central vacuole in concentrations of up to $0.5 \mathrm{M}$ (Fossing et al. 1995). These and other observations suggest that the marine Thioploca spp. commute up and down in their sheaths between the sediment surface, where they take up nitrate from the overlying seawater, and deeper parts of the sediment, where free hydrogen sulfide is available.

Because of the high biomass of Thioploca populations, they may play an important role in controlling the biogeochemistry of sediments in the oxygen minimum zone off Chile and Peru (Jørgensen \& Gallardo 1999). In the sea floor off Concepción, the Thioploca spp. transport large amounts of nitrate stored in the vacuole from the bottom water into the sediment, thereby increasing the total nitrate pool of the sediment by up to 100-fold (Thamdrup \& Canfield 1996). Different approaches have been used to estimate the fraction of produced sulfide which is oxidized by Thio- 
ploca spp. Based on the amount of labeled sulfide recovered in the pool of elemental sulfur after incubation and the average sulfate reduction rates, Ferdelman et al. (1997) concluded that 17 to $34 \%$ of the sulfide produced in the sediment could be re-oxidized by Thioploca spp., whereas based on $\mathrm{CO}_{2}$ uptake rates Thioploca spp. could account for only $18 \%$ of the sulfide oxidation. Much lower values were suggested by Thamdrup \& Canfield (1996), who estimate from depth-integrated nitrate consumption rates that 2 to $4 \%$ of the sulfide was oxidized with nitrate. Fossing et al. (1995) concluded from areal nitrate uptake rates measured in situ that up to $20 \%$ of the sulfide produced in the sediment was oxidized by nitrate presumably consumed by Thioploca filaments. In the absence of oxygen during most of the year, it is not clear how the rest of the sulfide is oxidized.

A general problem in estimating the significance of Thioploca spp. for sulfur and nitrogen cycling in Chilean and Peruvian sediments is the lack of knowledge concerning the population dynamics of Thioploca spp. Most earlier investigations on the abundance of Thioploca spp. did not provide accurate biomass data, as the principal method used for measuring biomass was sieving the sediment for Thioploca sheaths with $1.0,0.5$ or $0.25 \mathrm{~mm}$ sieves and taking the wet weight, dry weight or ash-free dry weight without distinguishing between living trichomes and dead sheath material (Gallardo 1977, Rosenberg et al, 1983, Gallardo 1985, Zafra et al. 1988, Gallardo et al. 1995). As the sheaths account for ca $90 \%$ of the wet weight (Schulz et al. 1996) but have no significance for the metabolic activity, the biomass including sheaths does not reflect the physiological potential of a Thioploca population.

In this study, the Thioploca population off the Bay of Concepción was sampled for $14 \mathrm{mo}$ at 4 to $6 \mathrm{wk}$ intervals to investigate whether seasonal changes in the upwelling intensity induce changes in the biomass and the species composition of the population. In March 1998 the sampling program was repeated in order to characterize the Thioploca population under 'El Niño' conditions. Thioploca spp. are much larger than normal bacteria and have distinct morphological characteristics. This enabled us to quantify and describe the population and its reaction to environmental changes directly on a species level by morphological observation, which is otherwise not possible for non-photosynthetic prokaryotes.

\section{MATERIALS AND METHODS}

Sampling. Four stations in the Bay of Concepción and the adjoining shelf area (Fig. 1) were sampled during 12 cruises on board the Chilean RV 'Kay Kay', of

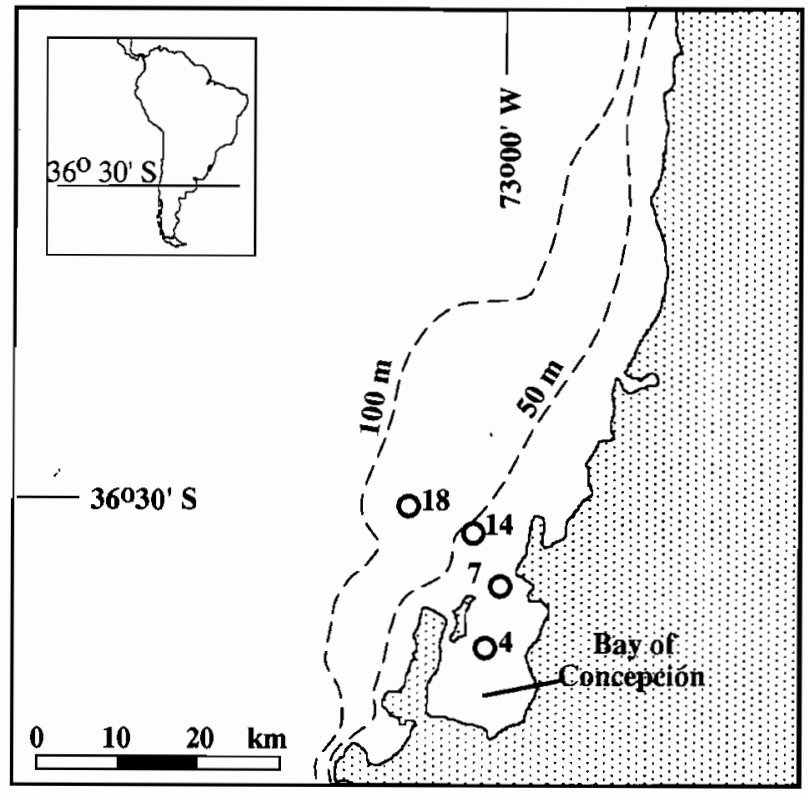

Fig. 1. Map of the sampling area (Chile) showing the Bay of Concepcion and the adjoining shelf area. The 4 stations are marked with open circles. The dashed lines (isobaths) indicate water depths

the University of Concepción. Sediment and bottom water samples were obtained from Stn $4\left(36^{\circ} 38^{\prime} 8^{\prime \prime} \mathrm{S}\right.$, $\left.73^{\circ} 02^{\prime} 3^{\prime \prime} \mathrm{W}\right)$, Stn $7\left(36^{\circ} 36^{\prime} 5^{\prime \prime} \mathrm{S}, 73^{\circ} 00^{\prime} 6^{\prime \prime} \mathrm{W}\right)$, Stn 14 $\left(36^{\circ} 32^{\prime} 1^{\prime \prime} \mathrm{S}, 73^{\circ} 03^{\prime} 0^{\prime \prime} \mathrm{W}\right)$, and $\mathrm{Stn} 18\left(36^{\circ} 30^{\prime} 8^{\prime \prime} \mathrm{S}\right.$, $73^{\circ} 07^{\prime} 6^{\prime \prime} \mathrm{W}$ ). Water depths were $24,32,64$ and $88 \mathrm{~m}$, respectively. Sediment samples were taken by a small Rumohr gravity-corer of $74 \mathrm{~mm}$ inner diameter and $1 \mathrm{~m}$ length. At each station, 3 cores were taken and immediately subsampled into Plexiglas tubes of $3.6 \mathrm{~cm}$ inner diameter and $30 \mathrm{~cm}$ length. Bottom water samples were taken with a 51 Niskin bottle ca $1 \mathrm{~m}$ above the sediment. Bottom water temperatures were 11 to $12^{\circ} \mathrm{C}$ throughout the year. At the end of May and beginning of June only 1 sediment sample for each station could be taken.

Bottom water oxygen and nitrate. Oxygen concentrations were measured by standard Winkler technique using $300 \mathrm{ml}$ bottles (Grasshoff 1983). Bottom water samples for later determination of nitrate (including nitrite) were stored frozen until injection into a bath of vanadium(III) chloride at $80^{\circ} \mathrm{C}$, which reduced nitrate and nitrite to nitric oxide. A continuous nitrogen flow through the bath led the nitric oxide into a $\mathrm{NO}_{\mathbf{x}}$ analyzer, where it was detected by chemiluminescence (Braman \& Hendrix 1989).

Biomass and species distribution. Subsampled sediment cores were stored in the laboratory at $5^{\circ} \mathrm{C}$ for up to $10 \mathrm{~d}$, open at the top and with 3 to $5 \mathrm{~cm}$ of bottom water over the sediment. The first subsampled 
core taken from each station was processed the following day and compared with cores processed within the following $10 \mathrm{~d}$ to check for changes in biomass or species distribution due to storage. Within $10 \mathrm{~d}$ no significant changes were observed. Subsampled sediment cores were extruded from the tubes and placed on a slightly tilted surface. The sediment around the sheaths was washed away carefully with sea water from a squirt bottle starting at the bottom of the core. One cm of sediment was consecutively washed away and the exposed sediment was examined for sheaths of Thioploca using a binocular microscope at $16 \times$ magnification. At each depth interval the exposed sheaths were counted and 5 sheaths were randomly picked for observation under the microscope. For each of the 5 sheaths, the diameter of the sheath was measured, the number of filaments counted, and the diameter of 1 filament and the length of 5 to 10 cells of this filament (Fig. 2) were measured at $1000 \times$ magnification. A preliminary investigation had shown that trichomes of 1 size class within a sheath have very similar diameters and cell lengths. In sheaths containing filaments of 2 or 3 different diameter classes, the number of filaments, the diameter and the cell length of each of those classes were measured separately.

Calculations. At each depth interval for each of the 5 picked sheaths the volume of Thioploca trichomes was calculated using the diameter of the trichomes, the number of trichomes in the sheath, and the average length of sheaths. The average length of sheaths at different sediment depths was determined in an earlier study where the 3-dimensional position of the sheaths in the sediment was investigated (Schulz et al. 1996) and could be used for this study. The average biovolume of the 5 sheaths removed at each depth interval was multiplied by the number of sheaths per $\mathrm{cm}^{2}$. The biovolumes at all depths were added up to give the total biovolume per unit surface area. The biomass of Thioploca filaments was calculated from biovolume assuming that the density of the trichomes is $1 \mathrm{~g} \mathrm{~cm}^{-3}$. The mean of 3 cores was calculated.

For all sheath and trichome parameters summarized in Table 1, the average, median and most frequent value at each time and station were calculated to evaluate whether the parameter followed a Gaussian distribution. For all parameters these 3 values yielded very similar results. Using the average values of theses parameters at each time and location, analysis of variance (ANOVA) was performed to see whether the values varied significantly between different months or between stations. The depth distribution did not follow a Gaussian distribution and therefore was excluded from this calculation.

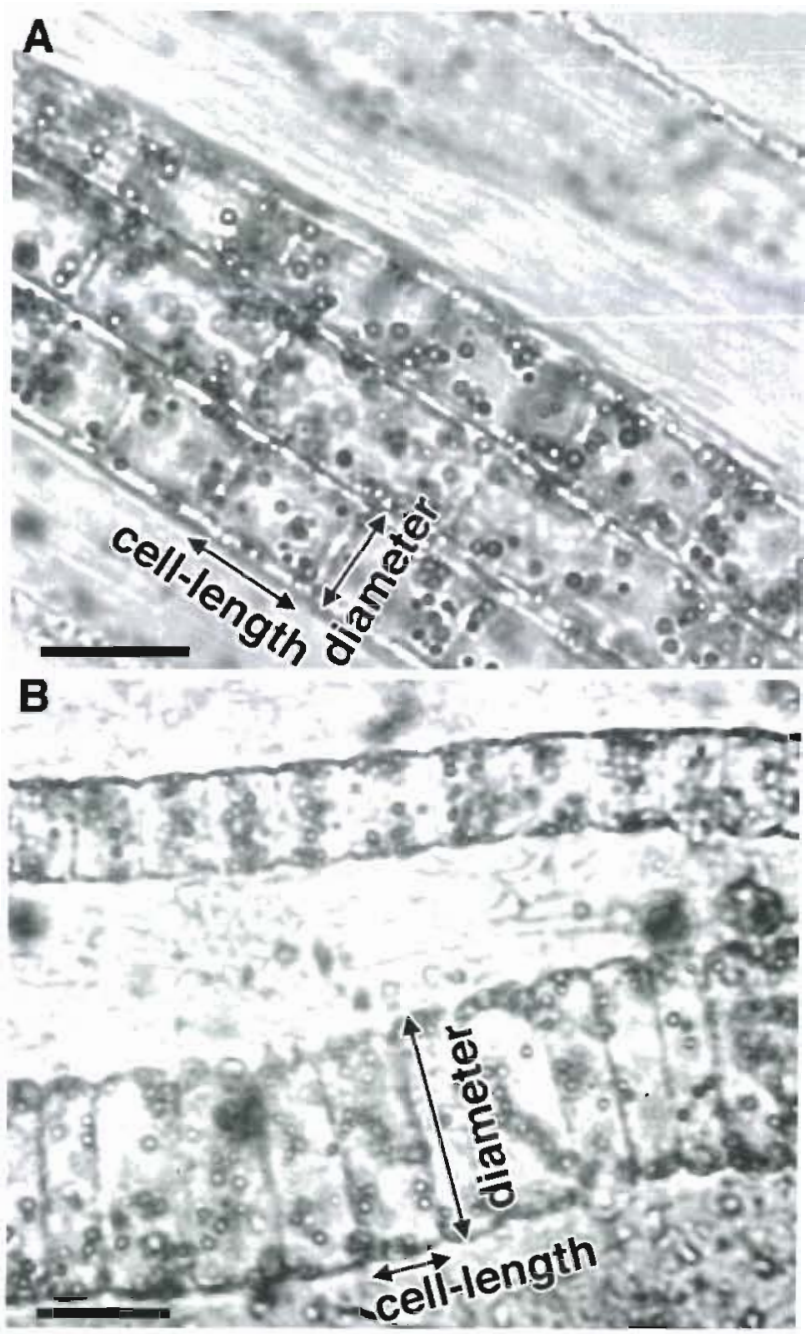

Fig. 2. Trichomes of Thioploca spp. in sheaths. (A) The long-cell morphotype, here $T$. araucae, with a normal ratio of cell-length to diameter. (B) Two short-cell trichomes with diameters of 35 and $75 \mu \mathrm{m}$ living in the same sheath. Scale bars $=50 \mu \mathrm{m}$

\section{RESULTS}

\section{Observations on different morphotypes}

During a preliminary study of the Thioplaca population in December 1995 it was observed that, in addition to the usual morphological form of Thioploca trichomes with cylindrical or slightly barrel-shaped cells, there was an undescribed morphotype with much shorter cells and rounded sides (Fig. 2B). To discriminate this morphotype from the known Thioploca spp. the cell-lengths of each trichome were measured and it became apparent that, using the ratio between average cell-length and trichome diameter, the population fell into 2 groups of ratios, $\leq 0.48$ and $>0.48$ (Schulz et al. unpubl.). The first group was 


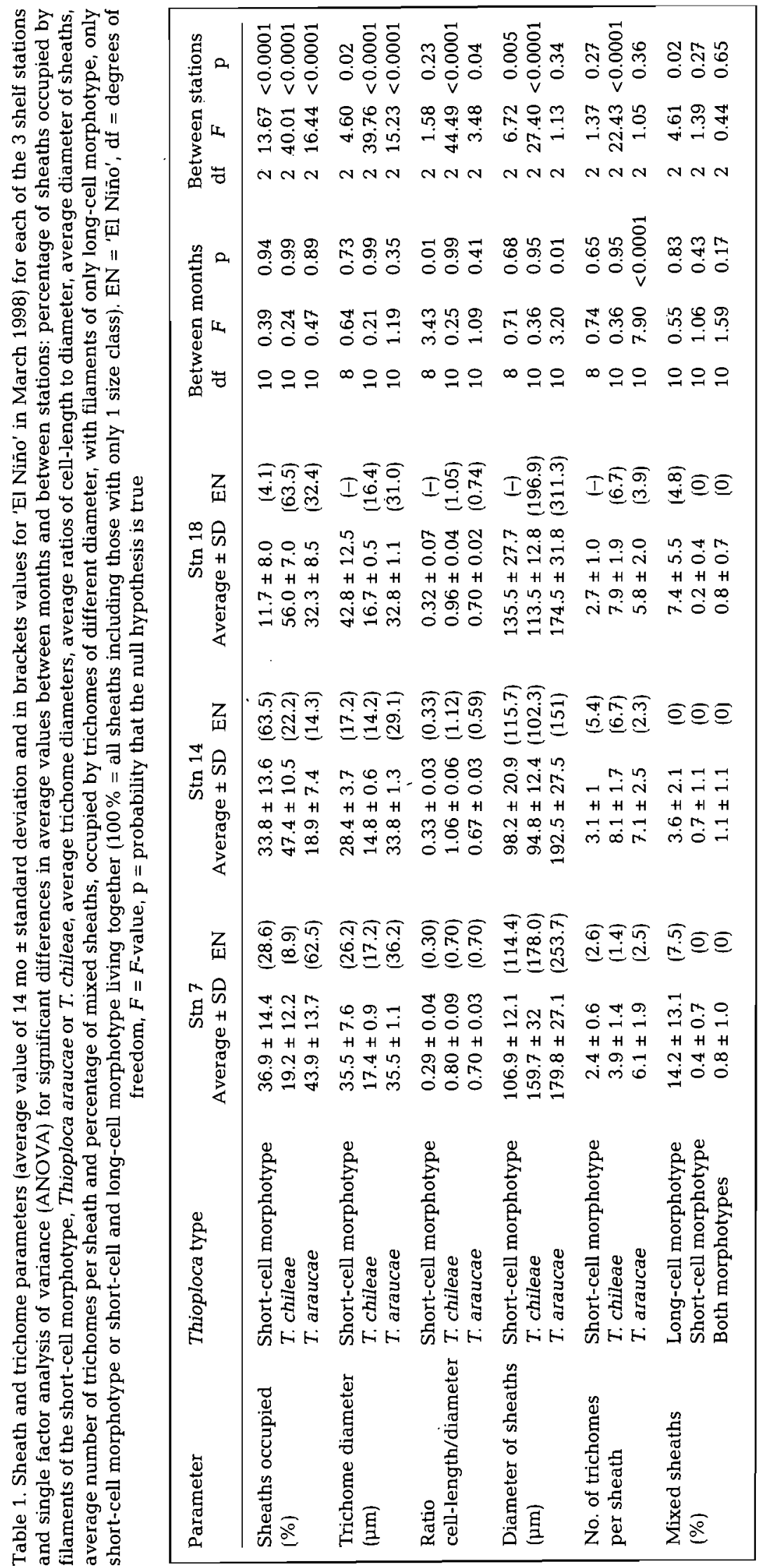

defined as the short-cell morphotype of Thioploca species. According to partial 16S rDNA sequences it is closely related but not identical to the known Thioploca species (Brinkhoff unpubl. results). The second group with ratios $>0.48$ contained $T$. chileae and $T$. araucae, which can be distinguished on the basis of their trichome diameters (Maier \& Gallardo 1984, Teske et al. 1995, Schulz et al. 1996).

\section{Bottom water parameters}

In the following discussion of seasonal variations it should be remembered that January is summer and July is winter. During the summer and fall months of January to June 1996 the bottom water overlying the sediment was almost oxygen free at all stations (Fig. 3A). In winter (July to September 1996) the oxygen concentrations increased to values around $20 \mu \mathrm{M}$ and decreased again to near zero in spring and early summer 1996 (November). During summer 1996/1997 oxygen concentrations were higher and more fluctuating than in the previous summer. Nitrate concentration was generally rather constant (10 to $30 \mu \mathrm{M}$ ). Lower values near zero were found only during August 1996 and March 1998 (Fig. 3B).

\section{Biomass}

The total biomass of Thioploca filaments at all stations was highest in summer 1996 (January to March) and declined during autumn (Fig. 3C). At Stn 18, which was furthest offshore, the biomass tended to be lower during summer 1996. During winter 1996 biomass remained low at all stations, but the Thioploca population never disappeared completely. In spring and summer 1996/1997 only the biomass at Stn 7 increased but remained lower than observed in the previous summer. The standard deviations of biomass between the 3 subcores were mostly 25 to $50 \%$ of the mean value. 

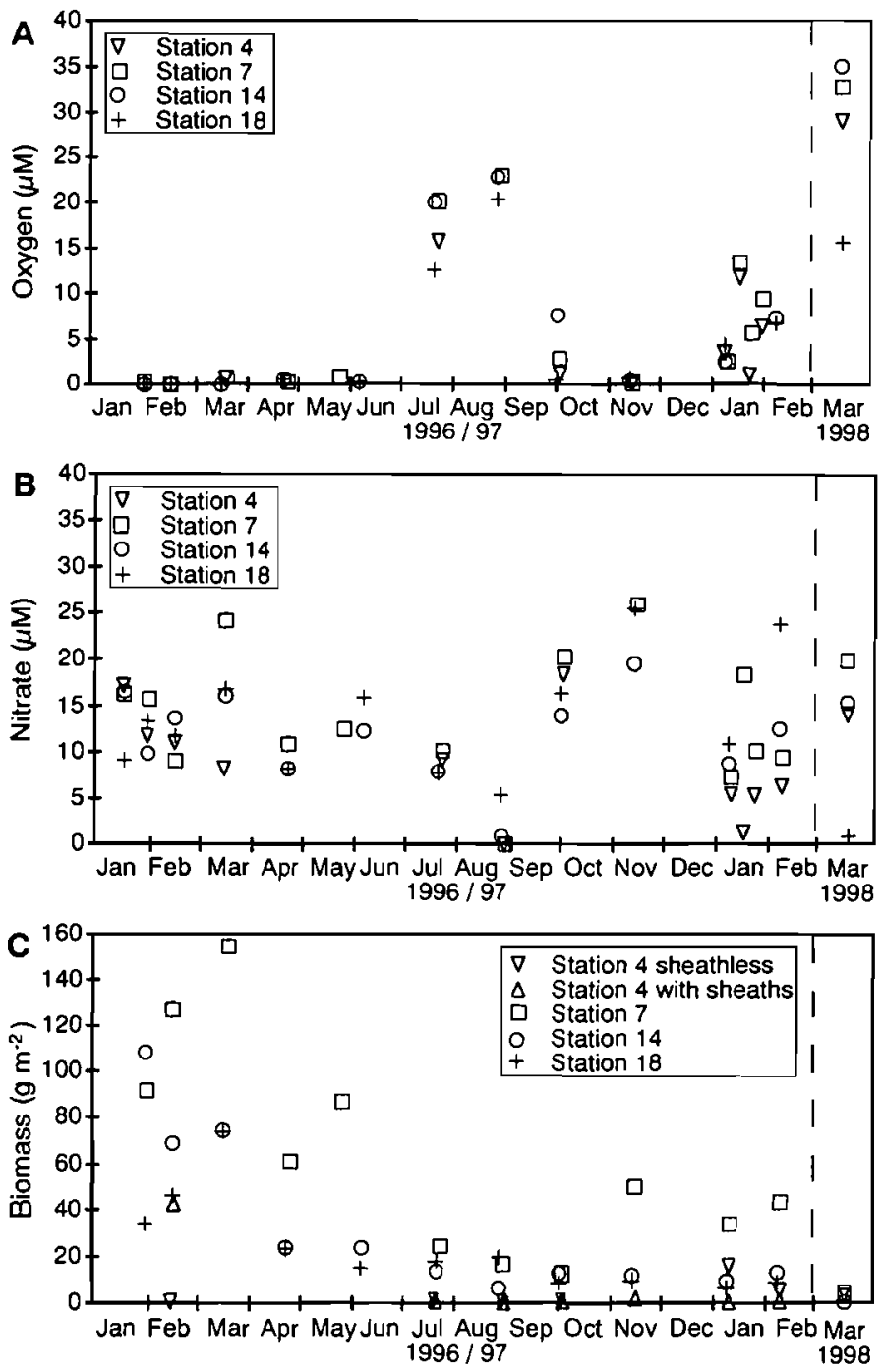

Fig. 3. Bottom water concentrations of (A) oxygen and (B) nitrate, and $(C)$ total biomass of Thioploca trichomes (without sheaths) measured from January 1996 until February 1997 and in March 1998

\section{Number of sheaths}

The total number of inhabited sheaths per $\mathrm{cm}^{2}$ generally followed the pattern of the total biomass, but the relationship between biomass and number of sheaths was slightly different for each station (Fig. 4). The percentage of sheaths occupied by 1 of the 3 different groups (Table 1) showed that the composition of the Thioploca communities did not change significantly with time but was significantly different between stations. At Stn 18, sheaths containing trichomes of the short-cell morphotype occurred rarely throughout the year, whereas they were more abundant at Stn 14 and even more so at $\operatorname{Stn} 7$. At Stns 14 and 18 sheaths con- taining $T$. chileae were more abundant than $T$. araucae throughout the year, while at Stn 7 sheaths containing T. araucae were more common.

\section{Depth distribution}

The highest biomass was generally found in the upper 0.5 to $1 \mathrm{~cm}$ of the sediment (Fig. 5). In August 1996, this depth increased at Stns 7 and 14, followed by Stn 18 in September 1996. At Stn 7 the depth of highest biomass returned to 0.5 to $1 \mathrm{~cm}$, while at Stn 14 it remained at $1 \mathrm{~cm}$ depth and at Stn 18 at $2 \mathrm{~cm}$. During the 14 mo of observation, the maximal depths at which Thioploca trichomes could be found changed considerably between 8 and $22 \mathrm{~cm}$. This was mainly due to short-cell trichomes which penetrated deepest into the sediment at all stations during the summers of 1996 and 1997. Long-cell filaments occurred to similar maximal sediment depths throughout the whole season. This depth decreased towards the coast (Fig. 5).

\section{Trichome parameters}

The average diameter of trichomes as well as the average ratio of cell-length to trichome diameter (Table 1) did not change significantly between different times of observation, with the exception of ratio of cell-length to diameter in short-cell trichomes. At Stn 14 the diameter of Thioploca chileae filaments was significantly smaller and the ratio of cell-length to diameter higher than at the other 2 stations, while T. araucae filament increased in diameter towards the coast.

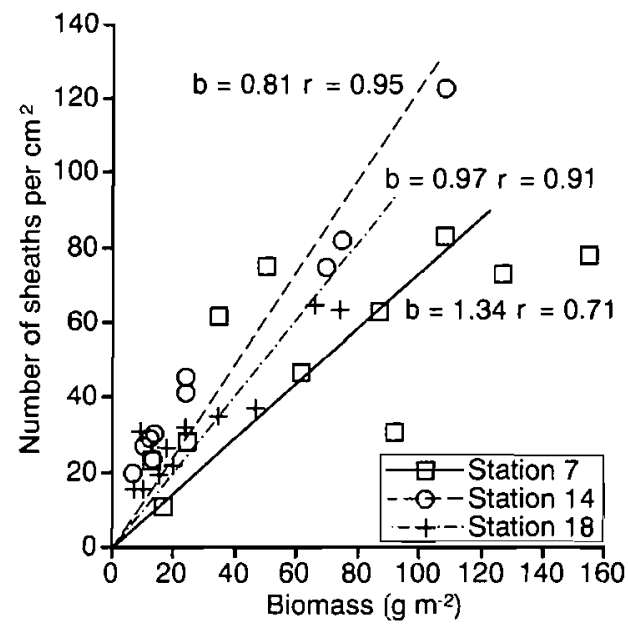

Fig. 4. Relation between the total number of Thioploca sheaths per $\mathrm{cm}^{2}$ and total biomass of Thioploca spp. in $\mathrm{g}$ wet weight $\mathrm{m}^{-2}$ for the 3 shelf stations 

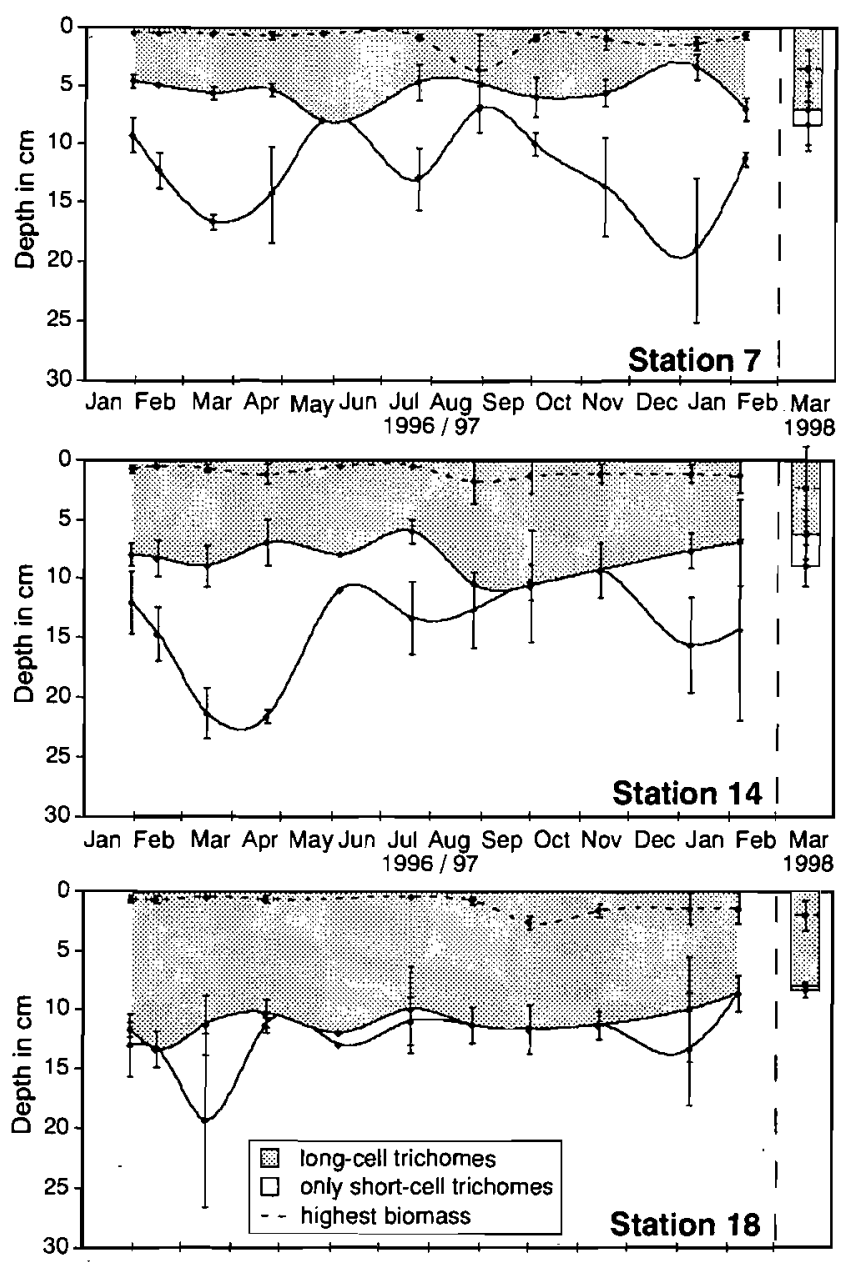

Jan Feb Mar Apr MayJun Jul Aug Sep Oct Nov Dec Jan Feb Mar

Fig. 5. Maximum downward extension of long-cell trichomes (Thioploca araucae and T. chileae) (gray) and short-cell trichomes (white) and the average depth of highest biomass density (dashed line) for each of the 3 shelf stations from January 1996 until February 1997 and in March 1998

\section{Sheath parameters}

The average diameter of sheaths and the number of trichomes per sheath was found to be significantly different between stations but not between months for sheaths filled with Thioploca chileae trichomes, while for sheaths containing $T$. araucae the opposite was found (Table 1). Sheaths containing $T$. chileae were smallest at Stn 14 and largest at Stn 7, although the number of filaments per sheath was much smaller at Stn 7 than at the other 2 stns.

Some sheaths contained filaments of 2 different size classes. These mixed sheaths were separated into 3 groups, 1 containing only trichomes of the long-cell morphotype (i.e. Thioploca araucae and T. chileae),
1 containing only short-cell filaments of 2 groups with different diameter, and 1 containing long-cell and short-cell trichomes mixed. The last 2 groups occurred very rarely at all stations (Table 1), never comprising more than $1 \%$ of all sheaths measured, while sheaths containing $T$. chileae and $T$. araucae together were much more abundant, showing the highest amount at Stn 7 and the lowest at Stn 14.

Occasionally, the smallest Thioploca species, Thioploca marina (2.5 to $5 \mu \mathrm{m}$ in diameter) (Maier 1989, Jørgensen \& Gallardo 1999), was observed in sheaths together with $T$. chileae or $T$. araucae, but their frequency could not be quantified, because the very small filaments are easily hidden by the larger filaments. In general, they appeared at all stations within the upper $3 \mathrm{~cm}$ of the sediment during most of the year.

\section{The Bay of Concepción}

Stn 4 , in the middle of the Bay of Concepción, was not constantly populated by typical Thioploca spp. and the type of population was different from the shelf stations. In February 1996 a population of short-cell Thioploca living in sheaths with a total biomass of $40 \mathrm{~g} \mathrm{~m}^{-2}$ was found in the upper $7 \mathrm{~cm}$ of the sediment (Fig. 3C). From July 1996 to February 1997 this short-cell population was also observed, but with very low biomass $\left(<1 \mathrm{~g} \mathrm{~m}^{-2}\right.$ ). In January and February 1997, sheathless filaments (per definition beggiatoas) with diameters typical for $T$. araucae were found on top of the sediment with a biomass of 15 and $5 \mathrm{~g} \mathrm{~m}^{-2}$, respectively. Similar populations were observed in February, July, August and October 1996, but with very low biomass. The bottom water oxygen and nitrate concentrations at Stn 4 were similar to the shelf stations (Fig. 3A,B).

\section{Observations during 'El Niño' in March 1998}

Oxygen concentrations measured in the bottom water in March 1998 were high compared to March 1996 (Fig. 3A), whereas nitrate concentrations were similar to earlier measurements (Fig. 3B). The total biomass of Thioploca spp. was even lower than in winter 1996 (Fig. 3C), and the total number of sheaths was correspondingly low. The average sediment depth of highest biomass was at 2 to $3 \mathrm{~cm}$ (Fig. 5). Average trichome diameters and ratios of cell-length to diameter of Thioploca trichomes remained mainly unchanged on the shelf stations, except for the short-cell trichomes and $T$. araucae at Stn 14, which decreased in diameter (Table 1). Sheath diameters were slightly greater, except for $T$. araucae at Stn 14, but the number of trichomes per sheath declined at all stations except for 
occurred with times of higher biomass (Fig. 3C) but a linear correlation could not be found.

\section{Population dynamics}

The biomass of Thioploca spp. on the shelf station showed significant changes between different times of the year $(F=3.85, \mathrm{p}=0.004)$. From the maximal increases in biomass between subsequent observations it is possible to estimate minimum doubling times of Thioploca spp. under natural conditions, assuming that there are no predatory losses or other mortality. The mean doubling time of biomass during periods of biomass increase was 38, 56 and $55 \mathrm{~d}$ at Stns 7, 14 and 18 whereas the minimum doubling times were 22,35 and $24 \mathrm{~d}$. Thus, it can be assumed that the maximum growth rates of Thioploca spp. under the environmental conditions correspond to a doubling time of approximately $3 \mathrm{wk}$, which compares well to the 26 to $52 \mathrm{~d}$ doubling time of filaments growing chemolithotrophically with acetate as a carbon source estimated from laboratory experiments with Thioploca spp. from Stn 7 (Otte et al. 1999).

At Stn 4 the population of sheathless trichomes at the sediment surface increased 14 -fold during September 1996, which corresponds to a doubling time of $5 \mathrm{~d}$. These filaments were found to be identical to Thioploca araucae according to their 16S rDNA sequence (Teske et al. 1999). As the population at Stn 4 was generally more patchy this apparently short doubling time is only a rough estimate. However, compared to chemoautotrophic marine Beggiatoa strains, which have doubling times of 1 to $4 \mathrm{~d}$ (Nelson \& Jannasch 1983, Nelson et al. 1986) the number might be realistic, although the Beggiatoa filaments were narrower (4 to $5 \mu \mathrm{m})$ and therefore should grow faster.

\section{Differences between shelf stations}

The biomass of Thioploca spp. generally increased towards the coast (Fig. 3C) with more short-cell trichomes (Table 1) that reached deeper into the sediment during summer (Fig. 5). The highest biomass of Thioploca spp. reported to date, $106 \mathrm{~g}$ per $0.1 \mathrm{~m}^{2}$, including sheaths, was found near Stn 7 (Gallardo 1977), which would correspond to ca $100 \mathrm{~g} \mathrm{~m}^{-2}$ without sheaths (Schulz et al. 1996). These variations across the shelf coincided with higher sulfate reduction rates and, thus, increased availibility of sulfide towards the coast (Ferdelman et al. 1997, B.S. et al. unpubl. data).

The relative abundances of Thioploca araucae, T. chileae and the short-cell morphotype were unaffected by seasonal changes but differed significantly among sta- tions (Table 1). T. araucae and short-cell filaments, which became more abundant towards the coast and occasionally populated the Bay of Concepción, seem to tolerate higher sulfide concentrations than $T$. chileae. The average trichome diameters of $T$. chileae and $T$. araucae did not vary seasonally (Table 1 ) but differed significantly between stations. A similar, remarkable invariance was observed for the ratios of celllength to diameter for these 2 species (Table 1). Thus, faster cell division during growth in summer did not lead to shorter cells than those found in winter. The diameter of trichomes is probably genetically determined, as is indicated by $16 \mathrm{~S}$ rDNA sequences (Teske et al. 1995), and the small differences in trichome diameter might indicate that each station was populated by slightly different subspecies of $T$. araucae and $T$. chileae. At Stn 14, where the relative proportion of $T$. araucae filaments was the lowest, the $T$. chileae filaments had shorter cells, their trichomes and sheaths were much smaller in diameter, the sheaths contained more trichomes and the number of mixed sheaths was on average 3 times lower than at Stns 7 and 18 (Table 1). Thus, it seems that there were no continuous changes in the population structure with higher water depths but each station has a specific composition of species and subspecies of Thioploca depending on local conditions. Concurrent with this finding, Gray et al. (1999) report a high diversity and degree of endemism for $16 \mathrm{~S}$ rDNA sequences recovered from Achromatium oxaliferum in different freshwater sediments in northern England (Gray et al. 1999).

The average diameter of sheaths and number of trichomes per sheath changed seasonally for Thioploca araucae, while for sheaths of $T$. chileae clear differences between stations were found (Table 1). At Stn 14 , sheaths of $T$. chileae were small while the average number of trichomes per sheath was high. The T. chileae sheaths at Stn 7 were the largest but contained the lowest number of trichomes. For the shortcell morphotype the number of trichomes per sheath was low at all stations, while the diameter of sheaths were large. Thus, diameter of sheaths and number of trichomes vary independently. At each station the dominating species had the highest number of trichomes per sheath irrespective of season. Since most sheaths were below $200 \mu \mathrm{m}$ in diameter and many below $100 \mu \mathrm{m}$ (Table 1), sieving with $1.0,0.5$ or even $0.25 \mathrm{~mm}$ sieves will lead to loss of sheaths. The resulting error is probably variable, as average sheath diameters differed among stations.

Sheaths with mixed species of Thioploca occurred with different frequency at each station (Table 1). Sheaths containing short-cell trichomes of different diameters ( $>5 \mu \mathrm{m}$ difference) and sheaths inhabited by short-cell trichomes together with $T$. araucae or 
short-cell trichomes at Stn 14 (Table 1). The number of mixed sheaths with trichomes of different size decreased at all shelf stations (Table 1). The proportion of the short-cell morphotype at Stn 7 and $T$. araucae at Stn 14 increased (Table 1). Generally, replicate samples showed larger heterogeneity than before with respect to distribution of morphotypes and total biomass. At Stn 4, a population of sheathless trichomes with diameters typical for $T$. araucae was found at the sediment surface at a biomass of $2 \mathrm{~g} \mathrm{~m}^{-2}$ (Fig. 3C).

\section{DISCUSSION}

\section{Seasonally changing parameters}

High biomass (Fig. 3C) occurred under low bottom water concentrations of oxygen (Fig. 3A), which are dependent on the hydrographic conditions. Under normal spring and summer conditions, long periods of strong southerly winds induce coastal upwelling, and equatorial subsurface water rich in nutrients and depleted in oxygen covers much of the continental shelf. During winter or 'El Niño' conditions, northerly winds dominate, which reduce the upwelling, and the shelf is covered by subantarctic water of lower salinity and higher oxygen concentrations (Strub. et al. 1998). The seasonal upwelling off the coast of Concepción was most pronounced during the summer 1995/1996, whereas in the summer 1996/1997 upwelling was less stable. Consequently, the oxygen content of the bottom water fluctuated more and the biomass of Thioploca spp. was significantly lower than in 1996/1997 (Fig. 3A).

On the shelf, sulfate reduction rates did not vary strongly between seasons (B.S. et al. unpubl. data). Thus, the increase in bottom water oxygen seems to have been the main reason for a decline in Thioploca biomass under winter conditions. High biomass ( $>50 \mathrm{~g}$ $\mathrm{m}^{-2}$ ) was only found when oxygen concentrations in the bottom water were below $2 \mu \mathrm{M}$ (Fig. 6). This is consistent with observations from the Peruvian upwelling areas, where highest biomasses of Thioploca spp. were clearly associated with low oxygen (Zafra et al. 1988). However, in contrast to observations by Gallardo (1985, 1995) and Zafra et al. (1988), the decrease in biomass was not generally accompanied by a decrease in the average number of trichomes per sheath (Table 1), but was mainly correlated with a decrease in the number of sheaths (Fig. 4), especially at Stns $14(\mathrm{r}=0.95)$ and $18(\mathrm{r}=0.91)$. At $\operatorname{Stn} 7$, this correlation was less pronounced $(\mathrm{r}=0.71)$, which is concurrent with significant seasonal changes of the number of trichomes per sheath for the dominant species $T$, araucae (Table 1). The decrease of total biomass and number of sheaths during winter 1996 was most prominent in the upper

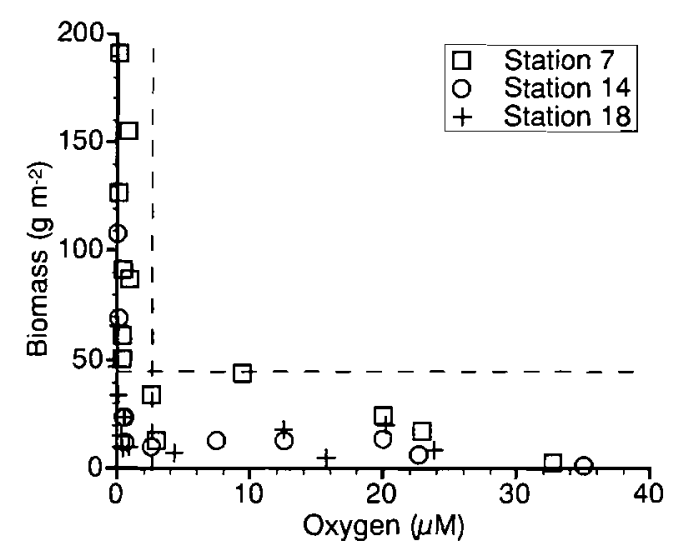

Fig. 6. Relation between biomass of Thioploca and oxygen concentration in the bottom water for the 3 shelf stations

$1 \mathrm{~cm}$ of the sediment, where most of the biomass is located during summer (Schulz et al. 1996). A month after higher oxygen concentrations appeared in the bottom water few sheaths could be found in the upper $1 \mathrm{~cm}$ of the sediment and, consequently, the highest biomass was found deeper in the sediment (Fig. 7). During the decline of the biomass, a high proportion of empty sheaths was occasionally found at the sediment surface, but these sheaths disappeared within the following month.

The maximal depth extension of the Thioploca population varied significantly with season $(F=3.42$, $\mathbf{p}=0.01$ ). During summer, filaments of the short-cell morphotype were found deepest down in the sediment (Fig. 5) but disappeared in autumn and winter, leaving behind empty sheaths which were often stained black from iron sulfide. The colonization of deeper parts of the sediment by short-cell filaments generally co-

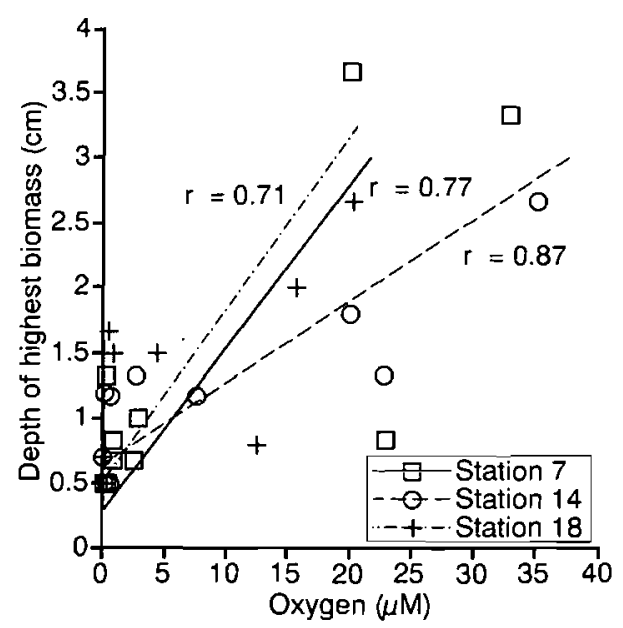

Fig. 7. Relation between depth of highest biomass and the oxygen concentration in the bottom water measured in the proceeding month for Stns 7,14 and 18 
Arntz WE, Flores LA, Maldonado M, Carbajal G (1985) Cambios de los factores ambientales, macrobentos y bacterias filamentosas en la zona de mínimo oxígeno frente al Perú durante 'El Niño' 1982-1983. In: Arntz W, Landa A, Tarazona J (eds) 'El Niño': su impacto en la fauna marina. Bol Inst Mar Peru (Spec Iss), Callao, 65-77

Braman RS, Hendrix SA (1989) Nanogram nitrite and nitrate determination in environmental and biological materials by Vanadium (IIl) reduction with chemiluminescence detection. Anal Chem 61:2715-2718

Ferdelman TG, Lee C, Pantoja S, Harder J, Bebout BB, Fossing $H$ (1997) Sulfate reduction and methanogenesis in a Thioploca-dominated sediment off the coast of Chile. Geochim Cosmochim Acta 61:3065-3079

Fossing $H$, Gallardo VA, Jørgensen BB, Hüttel M, Nielsen LP, Schulz H, Canfield DE, Forster S, Glud RN, Gundersen JK, Küver J, Ramsing NB, Teske A, Thamdrup B, Ulloa O (1995) Concentration and transport of nitrate by the mat-forming sulphur bacterium Thioploca. Nature 374:713-715

Gallardo VA (1977) Large benthic microbial communities in sulphide biota under Peru-Chile subsurface countercurrent. Nature 268:331-332

Gallardo VA (1985) Efectos del fenómeno de 'El Niño' sobre el bentos sublitoral frente a Concepción, Chile. In: Arntz W, Landa A, Tarazona J (eds) 'El Niño': su impacto en la fauna marina. Bol Inst Mar Peru (Spec Iss), Callao, p 79-85

Gallardo VA, Carrasco FD, Roa R, Cañete JI (1995) Ecological patterns in the benthic macrobiota across the continental shelf off central Chile. Ophelia 40:167-188

Grasshoff K (1983) Determination of oxygen. In: Grasshoff K, Ehrhardt M, Kremling K (eds) Methods of seawater analysis. Verlag Chemie, Weinheim, p 61-72

Gray ND, Howarth R, Rowan A, Pickup RW, Gwyn Jones J, Head IM (1999) Natural communities of Achromatium oxaliferum comprise genetically, morphologically, and ecologically distinct subpopulations. Appl Environ Microbiol 65:5089-5099

Jørgensen BB (1977) Distribution of colorless sulfur bacteria (Beggiatoa spp.) in a coastal marine sediment. Mar Biol 41: $19-28$

Jørgensen BB, Gallardo VA (1999) Thioploca spp.: filamentous sulfur bacteria with nitrate vacuoles. FEMS Microbiol Ecol 28:301-313

Maier S, Gallardo VA (1984) Thioploca araucae sp. nov. and Thioploca chileae sp. nov. Int J Syst Bacteriol 34: $414-418$

Editorial responsibility: Otto Kinne (Editor),

Oldendorf/Luhe, Germany
Maier S (1989) Thioploca Lauterborn 1907, 242 $2^{\mathrm{AL}}$. In: Staley JT, Bryant MP, Pfennig N, Holt JG (eds) Bergey's manual of systematic bacteriology, Vol 3. Williams \& Wilkins, Baltimore, p 2101-2105

Nelson DC, Jannasch HW (1983) Chemoautotrophic growth of a marine Beggiatoa in sulfide-gradient cultures. Arch Microbiol 136:262-269

Nelson DC, Jørgensen BB, Revsbech NP (1986) Growth pattern and yield of a chemoautotrophic Beggiatoa sp. in oxygen-sulfide microgradients. Appl Environ Microbiol 52: 225-233

Otte S, Kuenen JG, Nielsen LP, Paerl HW, Zopfi J, Schulz HN, Teske A, Strotmann B, Gallardo VA, Jørgensen BB (1999) Nitrogen, carbon, and sulfur metabolism in natural Thioploca samples. Appl Environ Microbiol 65:3148-3157

Rosenberg R, Arntz WE, Chumán de Flores E, Flores LA, Carabajal G, Finger I, Tarazona J (1983) Benthos biomass and oxygen deficiency in the upwelling system off Peru. J Mar Res 41:263-279

Schulz HN, Jørgensen BB, Fossing HA, Ramsing NB (1996) Community structure of filamentous, sheath-building sulfur bacteria, Thioploca spp., off the coast of Chile. Appl Environ Microbiol 62:1855-1862

Strub PT, Mesías JM, Montecino V, Rutllant J, Salinas S (1998) Coastal ocean circulation off western South America, Chap 10. In: Robinson AR, Brink KH (eds) The sea, Vol 11. Wiley \& Sons, New York, p 273-313

Tarazona JH, Arntz WE (1988) Oscillations of macrobenthos in shallow waters of the Peruvian central coast induced by El Niño 1982-83. J Mar Res 46:593-611

Tarazona JH, Arntz WE, Canahuire E (1996) Impact of two 'El Niño' events of different intensity on the hypoxic soft bottom macrobenthos off the central Peruvian coast. PSZN I: Mar Ecol 17(1-3):425-446

Teske A, Ramsing NB, Küver J, Fossing HA (1995) Phylogeny of Thioploca and related filamentous sulfide-oxidizing bacteria. Syst Appl Microbiol 18:517-526

Teske A, Sogin ML, Nielsen LP, Jannasch HW (1999) Phylogenetic relationship of a large marine Beggiatoa. Syst Appl Microbiol 22:39-44

Thamdrup B, Canfield DE (1996) Pathways of carbon oxidation in continental margin sediments off central Chile. Limnol Oceanogr 41:1629-1650

Zafra AH, Salzwedel H, Flores L (1988) Distribucíon y biomasa de bacterias filamentosas (Thioploca spp.) en la costa norte del Perú 1976-1985. IMARPE (Bol Extr) 1:99-105

Submitted: March 17, 1999; Accepted: January 27, 2000

Proofs received from author(s): June 16, 2000 
T. chileae were rare at all stations $(<1 \%)$, whereas sheaths containing $T$. chileae together with $T$. araucae were much more abundant ( 3 to $14 \%$ ). An earlier study (Schulz et al. 1996) showed that in $85 \%$ of mixed sheaths $T$. araucae was dominant. This and other observations led to the hypothesis that mixed populations form when trichomes, which stretch up into the bottom water, and then retreat into their sheaths, draw other trichomes with them. This may happen more easily in the larger sheaths of T. araucae. This hypothesis is supported by the observation that mixed sheaths were most abundant at Stn 7, where $T$. araucae dominated, and least abundant at Stn 14, where T. chileae dominated.

\section{The Bay of Concepción}

The areal sulfate reduction rates reported for Stn 4 are 3 to 4 times higher than for the shelf stations and, in contrast to the shelf sediments, free hydrogen sulfide regularly accumulates in the pore water up to the sediment surface (Ferdelman et al. 1997, B.S. et al. unpubl.). Probably as a result of this, Stn 4 was not continuously populated by Thioploca spp. and, occasionally, 2 distinct types of populations occurred. In the early summer of 1996, short-cell filaments populated the upper $7 \mathrm{~cm}$ at $\operatorname{Stn} 4$ in abundance $\left(40 \mathrm{~g} \mathrm{~m}^{-2}\right)$. For this period oxygen was not detectable in the bottom water, nitrate was present at $11 \mu \mathrm{M}$ concentration and the sediment smelled strongly of hydrogen sulfide (200 $\mathrm{\mu M}$ sulfide at the sediment surface in March 1996, B.S. et al. unpubl. data). During summer 1997, with high sulfide concentrations at the sediment surface ( $>400 \mu \mathrm{M}$, B.S. et al. unpubl. data), sheathless filaments populated the surface sediment with a biomass of up to $15 \mathrm{~g} \mathrm{~m}^{-2}$. Except for the absence of a sheath, these filaments looked identical to Thioploca araucae and they had the same 16S rDNA sequence (Teske et al. 1999). Consequently, they may be considered sheathless Thioploca spp. However, recent studies indicate that the nitrate-storing species of Thioploca and Beggiatoa are closely related (Ahmad et al. 1999. Jorgensen et al. unpubl.). Although the biomass was lower than on the shelf (10 to $160 \mathrm{~g} \mathrm{~m}^{-2}$ ), it is in the same range as the biomass of Beggiatoa spp. encountered in a Danish fjord ( 5 to $20 \mathrm{~g} \mathrm{~m}^{-2}$ ) (Jørgensen 1977). As both oxygen and nitrate were present in low concentrations ( 3 and $6 \mu \mathrm{M}$, respectively), it is not clear whether the sheathless filaments accumulated on the sediment because they switched to an oxic respiration, or whether they could still oxidize sulfide with the nitrate present, but without penetrating into the sediment. The latter seems more likely, since the filaments possessed a central vacuole and stored nitrate (Teske et al. 1999). Both types of populations seem to be able to endure higher sulfide concentrations than the Thioploca spp. found in shelf sediments. Nevertheless, the conditions in the Bay of Concepción do not support a stable population of sulfur bacteria. The general trend of higher fluctuations in the population towards the coast and a higher proportion of T. araucae and shortcell filaments continued into the bay.

\section{Effect of 'El Niño' 1998}

The effect of 'El Niño' on the biomass of Thioploca spp. has been described for both Chile (Gallardo et al. 1995) and Peru (Arntz et al. 1985, Tarazona \& Arntz 1988, Zafra et al. 1988, Tarazona et al. 1996). In many respects, the changes induced by the 'El Niño' were similar to the situation observed in winter only more pronounced. The Thioploca population on the shelf was strongly reduced, due to the prolonged absence of upwelling, the presence of oxygen, and the low sulfate reduction rates $\left(5\right.$ to $10 \mathrm{mmol} \mathrm{m} \mathrm{m}^{-2}$; B.S. et al. unpubl.). The highest biomass was found deeper in the sediment, as also observed in winter 1996 (Fig. 5). Some parameters that were independent of season also remained the same under 'El Niño' conditions, e.g. the average diameters and cell-lengths. However, the species composition at all stations changed, sheaths tended to be larger in diameter and contained less trichomes, and sheaths containing mixed trichomes occurred more seldom (Table 1). At Stn 4, bottom water oxygen and nitrate concentrations during 'El Niño' were comparable to the previous summer, and a similar population of sheathless filaments was found on the sediment surface, although lower in biomass.

Acknowledgements. We would like to thank the Captain of the RV 'Kay Kay', Miguel Monné, and the crew, Sergio Marileo and José Camaño, for their cooperation and helpfulness on board, as well as the staff and colleagues at the University of Concepción and the Station for Marine Biology in Dichato, especially Miguel Torres, Mario Baltazar, Jaime Henríquez and Gonzalo Cid. Special thanks are owed to Paula Urrutia, Vanessa Madrid and Anyola Vega for uncountable favors. We also thank Volker Brüchert for valuable comments on the manuscript. Observations during 'El Niño' were partly supported by FONDECYT Project No. 1971336 and CONICYT's FONDAP-HUMBOLDT program. The study was supported by the Max Planck Society, Germany, the University of Concepción, and the German Academic Exchange Service (DAAD).

\section{LITERATURE CITED}

Ahmad A, Barry JB, Nelson DC (1999) Phylogenetic affinity of a wide, vacuotate, nitrate-accumulating Beggiatoa sp. from Monterey Canyon, California, with Thioploca spp. Appl Environ Microbiol 65:270-277 